\title{
Bioethanol Production from Cellulose by Candida Tropicalis, as an Alternative Microbial Agent to Produce Ethanol from Lignocellulosic Biomass
}

\author{
Hermansyah $^{1, *}$, Novia $^{2}$, Maulin Wiraningsih ${ }^{3}$ \\ ${ }^{1}$ Chemistry Dept. Faculty of Mathematic and Natural Sciences, Sriwijaya University \\ ${ }^{2}$ Chemical Engineering Dept. Faculty of Engineering, Sriwijaya University \\ ${ }^{3}$ Graduate program Student, Chemical Engineering Dept. Faculty of Engineering, Sriwijaya University \\ *Corresponding author. email: hermansyah@unsri.ac.id \\ Article history

\begin{tabular}{llll}
\hline Received & Received in revised form & Accepted & Available online \\
7 March 2016 & 24 March 2016 & 30 March 2016 & 15 April 2016 \\
\hline
\end{tabular}

\begin{abstract}
Candida tropicalis isolated from Tuak is a potentially useful microorganism for the ethanol production from lignocellulosic biomass and it can be alternative agent replacing Saccharomyces cerevisae for fermentation process. Although $C$. tropicalis could not convert all carbohydrates content of lignocellulosic into bioethanol, however it is able to grow on medium in the presence of either xylose or arabinose as carbon source. Our result showed that fermentation of $10 \%(\mathrm{w} / \mathrm{v})$ cellulosic as sole carbon source produced $2.88 \%(\mathrm{v} / \mathrm{v})$ ethanol by $C$. tropicalis. This ethanol production was lower than usage of $10 \%(\mathrm{w} / \mathrm{v})$ dextrose as sole carbon source medium which producing $5.51 \%(\mathrm{v} / \mathrm{v})$ ethanol. Based upon our experiment indicated that $C$. tropicalis is able to conduct two main process in converting of cellulosic material- to ethanol which is hydrolysis the degradation of cellulose into glucose, and fermentation the process the conversion glucose into bioethanol.
\end{abstract}

Keywords: Candida tropicalis, bioethanol, fermentation, cellulosic

\begin{abstract}
Abstrak (Indonesian): Candida tropicalis yang diisolasi dari Tuak adalah agen yang berpotensi dalam produksi etanol dari biomassa lignoselulosa dan dapat dijadikan agen alternatif menggantikan Saccharomyces cerevisiae pada proses fermentasi. Walaupun $C$. tropicalis tidak dapat mengonversi semua kandungan karbohidrat lignoselulosa menjadi etanol, akan tetapi $C$. tropicalis mampu tumbuh pada media dengan xilosa atau arabinosa sebagai sumber karbon. Hasil kami menunjukkan bahwa dengan menggunakan C. ropicalis fermentasi $10 \%(\mathrm{w} / \mathrm{v})$ selulosa sebagai satu-satunya sumber karbon menghasilkan 2,88\% (v/v) etanol, Produksi etanol ini lebih rendah jika menggunakan $10 \%(\mathrm{w} / \mathrm{v})$ dekstrosa sebagai satu satunya sumber karbon yang menghasilkan 5,51\% (v/v) etanol. Berdasarkan percobaan menunjukkan bahwa $C$. tropicalis mampu melakukan dua proses utama dalam mengonversi material selulosa menjadi etanol yaitu hidrolisis degradasi selulosa menjadi glukosa, dan fermentasi proses konversi glukosa menjadi bioetanol.
\end{abstract}

Keywords: Candida tropicalis, bioetanol, fermentasi, selulosa

\section{Introduction}

Renewable energy is absolutely needed in order to anticipate depletion of fossil fuel stock because demand of human energy increased. Bioethanol is a potential energy for the future, not only abundant of raw material but also clean environment, because of ethanol combustion does not produce any pollutions. Utilization of ethanol replacing fossil fuel significantly reduces carbon dioxide emission since ethanol is part of global carbon cycle, and it could be produced by fermentation process. Ethanol previously has been known as antiknocking additive substance which added into gasoline since 1925 and it increased machinery efficiency and function of ethanol [1].

The first generation, bioethanol production utilized starch or grains, and for the second generation, raw material was lignocellulosic biomass such as rice hull, wheat husk, sugarcane bagasse, palm empty fruit bunch, corn stover, grasses and other household wastes. Thus, Lignocellulosic biomass is a promising alternative source of energy production because of a national abundance of renewable and sustainable feedstock. Lignocellulosic biomass is comprised of $42-50 \%$ cellulose (insoluble fibres $\beta-1,4$-glucan), $25-30 \%$ hemicellulose (non cellulosic polysaccharides including xylans, mannans, and glucans), lignin (a complex polyphenolic structure), and $5-8 \%$ extractive [2]. Bioconversion of lignocellulosic biomass to ethanol is environmentally friendly treatment of the most abundant lignocellulosic waste materials and alternative for sustainable green energy production. 
Three main common steps in second generation bioethanol production as follows 1) Pretreatment of lignin residue, 2) cellulosic and hemicellusic hydrolysis, 3) sugar fermentation. Pretreatment process aims to separate lignin and break the structure of lignocellulose, and it is one of the most expensive steps in the process of converting biomass [3] and lignin is non fermentable material. Some hydrolysis methods producing a fermentable monosaccharide from celluloses or hemicellulose have been developed. In fermentation reaction, one sugar molecule converted to two ethanol and two carbon dioxides molecules.

Yeast Saccharomyces cerevisiae is common microbial agent in fermentation converting sugar to ethanol. However, S.cerevisiae wild type is not be able to ferment pentose $\mathrm{D}$-xylose and L-arabinose, major monosaccharide in lignocellulose [4]. Utilization of lignocellulosic biomass as raw material should convert entire monosaccharides content to get optimum concentration of ethanol. The primary difficulty for commercialization of ethanol. produced by fermentation is its high cost of production comparing than gasoline production cost [5], therefore two simultaneous hydrolysis and fermentation could reduce production cost. Hence, exploration of other potential microorganism should be conducted. One of promising microbial agent for bioethanol fermentation from lignocellulosic material is Candida tropicalis isolated from Tuak [6]. C.tropicalis was known to produce ethanol from starch in low rate [7], however further experiments states that C.tropicalis is a promising agent to produce ethanol from renewable sources $[8,9]$. The advantage of using C.tropicalis in starch fermentation to ethanol is the process is unnecessary to perform saccharification step and the process resulting ethanol around $56 \mathrm{~g} / \mathrm{L}$. This produced ethanol is similar to fermentation using recombinant S.cerevisiae which express amylase and glucoamylase [7]. In this article shows us that yeast C.tropicalis has capability to bioconvert cellulose to ethanol without saccharification step.

\section{Experimental Sections \\ 2.1. Material and strains}

C.tropicalis yeast isolated from Tuak. YPD Broth media composed of $10 \mathrm{~g} / \mathrm{L}$ yeast extract, $20 \mathrm{~g} / \mathrm{L}$ peptone, $20 \mathrm{~g} / \mathrm{L}$ glucose autoclaved at $121^{\circ} \mathrm{C}, 15 \mathrm{psi}$ for 15 minutes. YPD10 media composed of $10 \mathrm{~g} / \mathrm{L}$ yeast extract, $20 \mathrm{~g} / \mathrm{L}$ peptone, $100 \mathrm{~g} / \mathrm{L}$ dextrose. YPC10 media composed of $10 \mathrm{~g} / \mathrm{L}$ yeast extract, $20 \mathrm{~g} / \mathrm{L}$ peptone, and $100 \mathrm{~g} / \mathrm{L}$ cellulose, YPX10 media composed of $10 \mathrm{~g} / \mathrm{L}$ yeast extract, $20 \mathrm{~g} / \mathrm{L}$ peptone, and $100 \mathrm{~g} / \mathrm{L}$ xylose, YPA10 media composed of $10 \mathrm{~g} / \mathrm{L}$ yeast extract, $20 \mathrm{~g} / \mathrm{L}$ peptone, and $100 \mathrm{~g} / \mathrm{L}$ arabinose.
Phenotype test of yeast strain was carried out following a modified previous procedure [10]. Cells were streaked on YPD media to get single colonies, and then single colonies were streaked on YPD media with the carbon source either of $2 \%$ glucose, $2 \%$ xylose, or $2 \%$ galactose and incubated on room temperature for $1-$ 2 days.

\subsection{Ferments}

C.torpicalis isolate or S.cerevisiae BY4741 cells were cultured in YPD medium room temperature for overnight, and these cells were transferred to fermentation medium YPC10, with initial cell density was adjusted to $\mathrm{OD}_{600}=0.1$. Fermentation was performed using culture tubes $(18 \times 175 \mathrm{~mm})$ with working volume of $10 \mathrm{ml}$ YPD10, YPC10, YPX10, and YPA10. medium at room temperature incubation for 12 days. The bioethanol concentration from fermentations were determined by using Gas Chromatography Shimadzu 5810 plus with operational condition as follows: Temperature of Column $110^{\circ} \mathrm{C}$, temperature of FID detector $240{ }^{\circ} \mathrm{C}$, temperature of injection port $200^{\circ} \mathrm{C}$, rate of nitrogen carrier gas 50 $\mathrm{ml} / \mathrm{min}$.

\section{Result and Discussion}

In previous research showed that $C$. tropicalis has advantage in bioethanol production fermentation such as having higher growth rate than $S$. cerevisiae, able to grow on arabinose or xylose as sole carbon source [6]. Cellulose is one of the most important component in lignocellulosic biomass, and could be converted to ethanol. Fermentation for 1 day showed that C.tropicalis is capable to hydrolyze and ferment cellulose to bioethanol as shown on Fig.1a. Based on our GC condition, ethanol peak had retention time $1.98 \mathrm{~min}$. Ethanol concentration produced by fermentation using cellulose as sole carbon source was lower than using dextrose as sole carbon source. For one-day fermentation process using YPC10 or $10 \%(\mathrm{w} / \mathrm{v})$ cellulose containing medium produced $2.88 \%$ or 28.8 $\mathrm{g} / \mathrm{L}$ ethanol, while using YPD10 or 10\% (w/v) dextrose containing medium produced $5.51 \%(\mathrm{w} / \mathrm{v})$ ethanol or $55.1 \mathrm{~g} / \mathrm{L}$ (Fig. 1b).

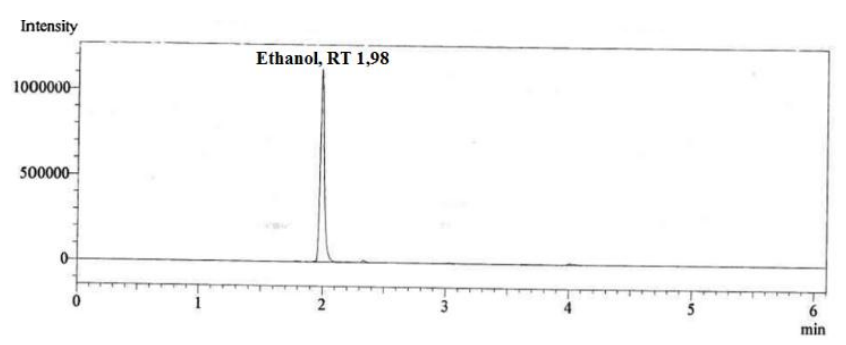

Figure 1a. Qualitative and Quantitative Analysis of ethanol production from cellulose containing medium

\subsection{Phenotype test}




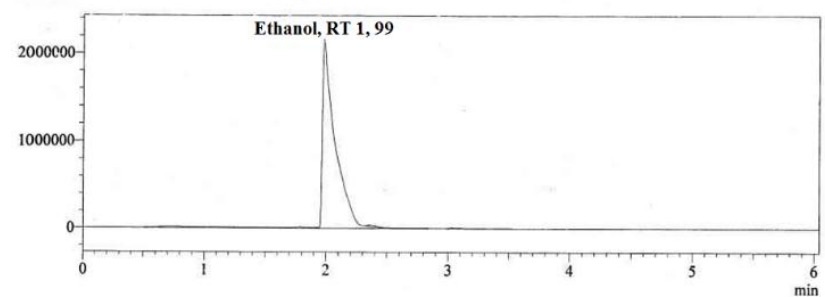

Figure 1b. Qualitative and Quantitative Analysis of ethanol production from dextrose containing medium

Based upon these results indicated that $C$. tropicalis was able to hydrolyze cellulose to glucose and then finally convert to ethanol. If $2,88 \% \mathrm{w} / \mathrm{v}$ or $28.8 \mathrm{~g} / \mathrm{L}$ ethanol was produced, and its stoichiometry means this reaction using $56.35 \mathrm{~g}$ glucose. While YPC10 medium containing $100 \mathrm{~g}$ cellulose per litre. This data indicated that hydrolysis using $C$. tropicalis resulted more than $50 \%$ glucose product. Cellulose is homopolysaccharides comprised of $\beta$-D-glucopyranose with $\beta$-glycosidic bond, and cellobiose is the smallest repetition unit from cellulose dan it can be converted into glucose rsidue [2]. Three groups enzymes play a role in hydrolyzing cellulose to glucose endoglucanase, cellobiohydrolase (exoglucanase), and $\beta$-glucasidase. To furthermore study, it is needed to carry out further experiments what kind of enzymes play a role in this hydrolysis process.

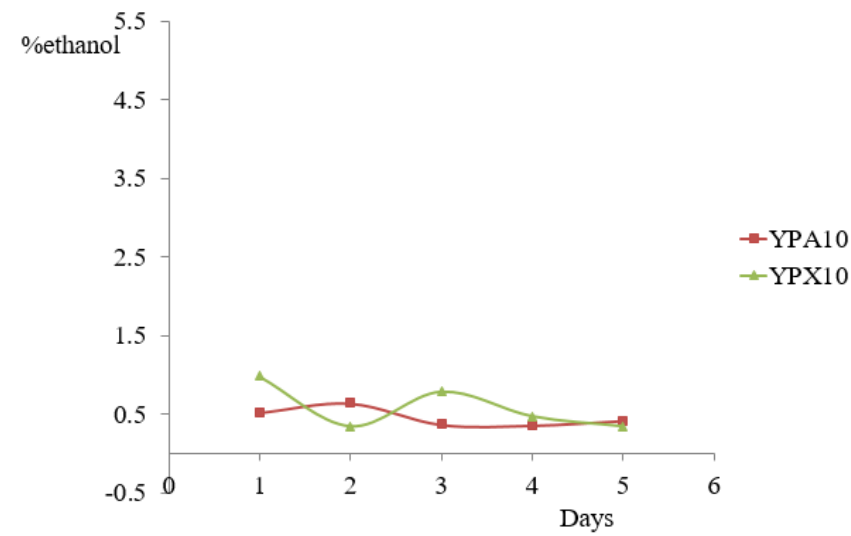

Figure 2a. Ethanol production in the presence of xylose and arabinose

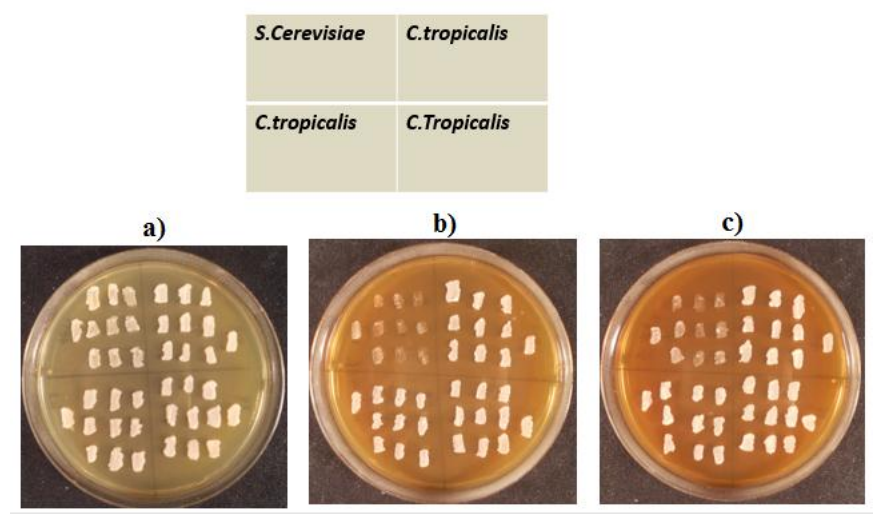

Vol. 1 No. $1,10-13$
Figure 2b. Phenotype tests C.tropicalis on a) YPD media; b) Xylose meium; c) arabinose medium

Fermentation using YPA10 or YPX10 media in the presence of $10 \%(\mathrm{w} / \mathrm{v})$ arabinose and $10 \%(\mathrm{w} / \mathrm{v})$ xylose as sole carbon source respectively incubation until 5 days showed no ethanol product (Fig. 2a). On other hand, phenotype test to several $C$. tropicalis colonies showed that all single colonies grew well on arabinose and xylose media, while S.cerevisiae did not (Fig. 2b). These data indicated that both arabinose and xylose are utilized as carbon source for growth, but they cannot be converted to ethanol, therefore we propose a model how C.tropicalis bioconverting cellulose to ethanol as shown in Fig. 3.

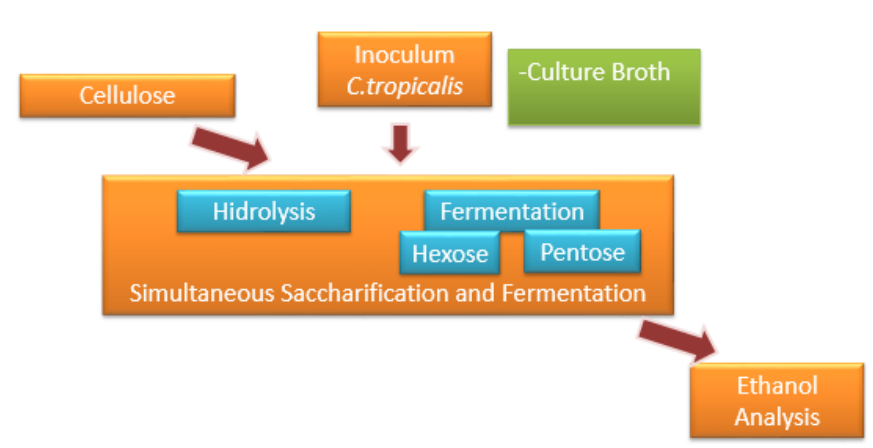

Figure 3. Model Bioconverting cellulose to ethanol by C.tropicalis.

\section{Conclusion}

C.tropicalis isolate is capable of hydolyzing and fermenting cellulose to produce bioethanol. Bioethanol is produced by bioconverting through metabolizable monosaccharide glucose, but not for monosachharides pentose such as arabinose and xylose. As major component of lignocellulosic material, this result indicates that C.tropicalis could be applied as microbial agent for bioconverting lignocellulosi biomass to ethanol.

\section{Acknowledgement}

The authors would like to thank to PNBP Sriwijaya University Indonesia for financial support of this research project.

\section{References}

[1] Antoni, D., Zverlov, V.V., and Schwarz, W.H., 2007, Biofuels from microbes, Appl. Microbiol. Biotechnol, 77: 23-35.

[2] Kumar, R., Singh, S., and Singh OV., 2008, Bioconversion of lignocellulosic biomass: biochemical and molecular perspective, J. Ind. Microbiol. Biotechnol. ,35: 377-391.

[3] Binod P, Satyanagalakshmi K, Sindhu R, Janu KU, Sukumaran RK, Pandey A. Short duration microwave 
assisted pretreatment enhances the enzymatic saccharification and fermentable sugar yield from sugarcane bagasse. Renew Energ. 2012; 37: 109-116.

[4] Karhumaa, K., Wiedemann, B., Hann-Hagerdal, B., Boles, E., Gorwa-Grauslund, M.F., 2006, Coutilization of L-arabinose and D-xylose by laboratory and industrial Saccharomyces cerevisiae strains, Microbial Cell Factories, 5-18: 2859-5-18.

[5] Mielenz, J.R., 2001, Ethanol production from biomass: technology commercialization status, Current opinion in Microbiology, 4: 324-329.

[6] Hermansyah, Novia, Sugiyama, M., Harashima, S., 2015, Candida tropicalis isolated from Tuak, a North Sumatera-Indonesia traditional beverage for bioethanol production, Microbiol. And Biotechnol. Letter 43 (3), 241-248.

[7] Jamai L., Ettayebi, K., El Yamani, J., Ettayebi, M.. 2007, Production of ethanol from starch by free and immobilized Candida tropicalis in the presence of amylase, Bioresour. Technol., 98: 2765-2770,

[8] Ettayebi, K., Errachidi, F., Jamai, L., Tahri-Jouti, M.A., Sendide, K., and Ettayebi, M., 2003, Biodegradation of polyphenols with immobilized Candida tropicalis under metabolic induction. FEMS Microbiol. Lett., 223, 215-219.

[9] Klinke, H.B., Thomsen, A.B., Ahring, B.K., 2004, Inhibition of ethanolproducing yeast and bacteria by degradation products produced during pre-treatment of biomass, Appl. Microbiol. Biotechnol., 66, 10-26.

[10] Hermansyah, Sugiyama, M., Kaneko, Y., and Harashima, S., 2009. Yeast protein phosphatase Ptp2p and Msg5p are involved in G1-S transition, CLN2 transcription, and vacuole morphogenesis, Arch. Microbiol , 191: 721-733 